\title{
Emerging models of social enterprise in Eastern Asia: a cross-country analysis
}

\author{
Jacques DEFOURNY \\ Centre for Social Economy, HEC Management School,University of Liege,Belgium \\ EMES European Research Network

\section{Shin-Yang KIM} \\ Civil Society \& Welfare Department, Sungkonghoe University, Seoul, South Korea \\ University of Paris 10 Nanterre, France
}

This paper will be published in a special issue of the Social Enterprise Journal entitled Social Enterprise in Eastern Asia, edited by Jacques Defourny and Yu-Yuan Kuan, Spring 2011 


\section{Introduction}

Field organisations corresponding to what we now call "social enterprises" have existed in many regions since well before the early or mid-1990s, when the term began to be increasingly used in both Western Europe and the United States. Indeed, the third sector, be it called the non-profit sector, the voluntary sector or the social economy, has long witnessed entrepreneurial dynamics which resulted in innovative solutions for providing services or goods to persons or communities whose needs were met neither by private companies nor by public providers.[1] However, for reasons which vary from region to region, the concept of social enterprise - along with two closely related notions, namely "social entrepreneur" and "social entrepreneurship" - is now gaining a fast growing interest to designate such new dynamics within the third sector as well as the emergence of economic activities with a social aim beyond the third sector's borders.

Although the very notion of the third sector can still be questioned in some East Asian contexts, it is clear that all five East Asian countries or special territory (Hong Kong) covered by the preceding articles in this issue are experiencing a development of diverse types of initiatives which can be considered, to varying degrees, as social enterprises. As argued in the volume's overall introduction, the goal pursued by the contributors to this joint project was to deepen the understanding of the "social enterprise phenomenon", acknowledging the influence of US or UE-centred approaches but also identifying all the factors and features that give specific East Asian colours to this phenomenon. Moreover the question was raised of the existence, or not, of truly specific models of social enterprise in Eastern Asia.

In this paper, although a much broader literature will be used as well, we first build our analysis upon the research results presented in the four preceding papers.[2] However, we do not want to merely synthesise those results. Instead, we use them to emphasise key dimensions along which China, Hong Kong, Japan, South Korea and Taiwan can be compared with each other as well as with other regions. In such a perspective, we analyse the historical and current socio-economic contexts (section 1) as well as the key factors and driving forces (section 2) which led to the emergence of social enterprise in each of these countries. As we try to pave the way for some comparative analysis with other regions, we also pay attention to the interactions which took place with social enterprise developments and schools of thoughts in Western Europe and the United States in the last decade (section 3). On the basis of country studies presented in this volume and elsewhere, we then propose a typology of the social enterprise models which can be found, although to various extents, throughout Eastern Asia; five broad models are identified in this perspective (section 4). Finally, we 
address the question of the very specificities of the social enterprise phenomenon in this region by looking at some underlying conditions for the emergence and development of third sector organisations, which were identified in European and American history, and we question their existence in Eastern Asia (section 5).

\section{Historical backgrounds and current socio-economic contexts in Eastern Asia}

The historical background of China, Japan, South Korea, Taiwan and Hong Kong is quite heterogeneous in terms of geo-political situation. From the last decades of the 19th or the beginning of the $20^{\text {th }}$ century onward, the old order, governed by Confucius thought and Buddhism, underwent deep transformations under an increasing influence of Western civilisation, and each of the five countries/territory took a specific development path, either for ideological reasons or because of imperial wars. However, in spite of significant divergences as to economic performance, these countries share similar socio-cultural backgrounds, especially at two levels that are of major interest for our purpose: the people's attitude toward the central public authority (government), on the one hand, and the relatively "uncertain" idea of civil society in the general public, on the other hand. More precisely, the state is seen as a homeland to defend[3] rather than as a contractual entity in charge of guaranteeing individual security. As for the concept of civil society, it has developed late in the $20^{\text {th }}$ century and is still unknown to ordinary people, who are more familiar with neighbourhood or informal networks at different levels.

\section{The central place of the state}

Most current studies on East Asian welfare regimes tend to quasi unanimously underline common characteristics: Confucian culture, state-driven development strategy, weak civil society, authoritarian political regime, hierarchical social relationships and gender inequality. One of the pioneers on this topic put forward terms like "oikosmic welfare state" or "Confucian welfare state" to highlight these countries' characteristics, based on private rather than public protection (Jones, 1993). In the last decade, Wilding (2008) stressed a model of a "productive welfare state", based on selectiveness, work incentives and "re-commodification" - instead of universalism - of social rights. As to authors from this region, many of them seem to agree on the concept of "developmental welfare state" (Kwon, 2005): the "development ideology" is indeed very strong in these societies, and welfare provision is often seen as a tool, among other tools, in the perspective of investment and development strategies, while also being an instrument to 
cope with the legitimacy crisis of the political power.

\section{An emerging civil society}

Beyond common features, it is important to note that South Korea and Taiwan experienced democratisation in the early 1990s, Hong Kong was reintegrated into China in 1997 whereas democracy had already been stabilised for several decades in Japan. Civil society organisations are now developing significantly in all countries but their quantitative growth is not necessarily synonymous with qualitative advance, as the latter heavily depends on their degree of autonomy, especially with respect to the state. Indepth research remains to be done on this issue, and it is difficult to propose reliable criteria to evaluate each country's situation in this regard.

\section{The crisis of the 1990s}

Referred to, as just said, as "Confucian" or "developmental", welfare regimes in East Asian countries have developed rather late and in a discontinuous way. Except in China, they were strongly affected during the 1990s: they had to cope with employment and redistribution crises caused by structural changes such as the dislocation of the manufacture industry and an overall process of de-industrialisation related to accelerated globalisation. The rise of unemployment was particularly sharp in South Korea and Hong Kong after the financial crisis of 1997, but Japan and Taiwan also faced an increase of the unemployment rate, which reached up to $5 \%$ in the early $2000 \mathrm{~s}$, as shown in table 1.

Table 1 - Unemployment rate in East Asian countries from 1990 to 2007

\begin{tabular}{|l|r|r|r|r|r|r|r|r|r|r|r|r|r|r|}
\hline & 1990 & 1995 & 1996 & 1997 & 1998 & 1999 & 2000 & 2001 & 2002 & 2003 & 2004 & 2005 & 2006 & 2007 \\
\hline China & 2.5 & 2.9 & 3.0 & 3.1 & 3.1 & 3.1 & 3.1 & 3.6 & 4.0 & 4.3 & 4.2 & 4.2 & 4.1 & 4.0 \\
\hline HK & 1.3 & 3.2 & 2.8 & 2.2 & 4.7 & 6.2 & 4.9 & 5.1 & 7.3 & 7.9 & 6.8 & 5.6 & 4.8 & 4.0 \\
\hline SK & 2.4 & 2.1 & 2.0 & 2.6 & 7.0 & 6.3 & 4.1 & 4.0 & 3.3 & 3.6 & 3.7 & 3.7 & 3.5 & 3.2 \\
\hline Taiwan & 1.7 & 1.8 & 2.6 & 2.7 & 2.7 & 2.9 & 3.0 & 4.6 & 5.2 & 5.0 & 4.4 & 4.1 & 3.9 & 3.9 \\
\hline Japan & 2.1 & 3.2 & 3.4 & 3.4 & 4.1 & 4.7 & 4.7 & 5.0 & 5.4 & 5.3 & 4.7 & 4.4 & 4.1 & 3.9 \\
\hline
\end{tabular}

Source: KIHASA social protection monitoring centre.

In spite of economic growth and increased public expenditure to meet social needs, income inequality and poverty problems have also grown steadily, as shown in table 2 , especially because of the deterioration of the income redistribution system. Indeed, beyond unemployment, a crucial challenge for East Asian countries is the growing 
proportion of "working poor": while unemployment rate started to fall after a few years of increase, the growing importance of the service sector indirectly resulted in a structural employment problem, as low-income and insecure jobs are more common in this sector.

Table 2 - Evolution of the poverty rate and income inequality between 1990 and 2005

\begin{tabular}{|c|c|c|c|c|}
\hline & & $\mathbf{1 9 9 0}$ & $\mathbf{2 0 0 5}$ & Variation \\
\hline \multirow{4}{*}{ Poverty rate } & SK & $11.3 \%$ & $16.4 \%$ & $+45.1 \%$ \\
\cline { 2 - 5 } & Japan & $13.2 \%$ & $14.9 \%$ & $+12.8 \%$ \\
\cline { 2 - 5 } & HK & $11.2 \%$ & $17.7 \%$ & $+58.0 \%$ \\
\cline { 2 - 5 } & Taiwan & $6.5 \%$ & $9.6 \%$ & $+47.7 \%$ \\
\hline \multirow{2}{*}{$\begin{array}{c}\text { Income } \\
\text { inequality } \\
\text { (Gini) }\end{array}$} & SK & 0.291 & 0.334 & $+14.8 \%$ \\
\cline { 2 - 5 } & Japan & 0.398 & 0.498 & $+25.1 \%$ \\
\cline { 2 - 5 } & HK & 0.476 & 0.533 & $+12.0 \%$ \\
\cline { 2 - 5 } & Taiwan & 0.271 & 0.305 & $+12.5 \%$ \\
\hline
\end{tabular}

Source: No et al. (2008), p. 80.

\section{Social enterprises as responses to structural changes}

The emergence of social enterprises in East Asian countries is closely linked to the socio-economic changes of the late 1990s and to the early attempts of civil society organisations to cope with new social problems. As far as public authorities are concerned, they began to pay attention to those new initiatives as they had to consider new policy measures and programs to meet the growing welfare needs.

However, the raisons d'être of social enterprises and their mode of survival vary according to the socio-cultural tradition of each society, because they are created to meet specific needs of that society by mobilising diverse economic and social resources and through interaction between different actors. Therefore, the concept of social enterprises is not a stable one; it tends to evolve in its specific environment.

\section{Major common trends}

The concept of social enterprise as such was introduced in East Asian countries around 2000; it has spread rapidly during the last decade, not only among third sector organisations but also among researchers and government officers. It has been evolving along with different approaches; consequently, it does not have any commonly accepted definition, except in South Korea, where a specific law giving a definition of social 
enterprise was enacted in late 2006 to promote social enterprises. But beyond divergences, it is possible to identify common denominators which contribute to explain the emergence of the social enterprise phenomenon in Eastern Asia:

- first, the growing role of NPOs as social services providers in the framework of changing welfare regimes (privatisation, welfare-to-work or social investment);

- secondly, the change of public policy toward a culture of contracting with NPOs, which leads the latter to adopt a market-oriented approach and to compete for public contracts;

- thirdly, the "soft landing" of the concept of "corporate social responsibility" (CSR) in the field of social entrepreneurship, and the setting up of an increasing number of foundations by for-profit enterprises;

- fourthly, changes in NPOs' strategy with a view to diversifying the resources and ensuring the sustainability of activities;

- fifthly, to a certain extent, a renewed aspiration for alternative economic practices on the part of civil society organisations and the academic world, which witnessed the harmful effects of neoliberal globalisation (structural adjustment programs, impacts of speculative capital flows, environmental destruction, etc).

The relative impact of these various factors varied according to the national context. For instance, the fifth factor has been the most important motive behind the creation of civil society organisations in Japan and South Korea, whereas the second factor has been the main motive accounting for the creation of NPOs in Hong Kong and Taiwan.

\section{Key roles of pioneer initiatives and public policies}

In Japan and South Korea, the origin of the social enterprise phenomenon might be found in the movement aiming to fight unemployment through the development of new employment opportunities in the third sector. The "business units for the unemployed", organised by the workers' co-operative movement, the "common workshops for the disabled" and the "workers' collectives" of married women around the 1980s were the pioneer initiatives in Japan (Kanno, 2000). In the same vein, in South Korea, the "onestop service centres for the unemployed" (OSCUs) started in 1998 to organise "public work business units" at the national level, with a view to creating new types of jobs, with a social utility, for and by the participants in the "Public Work Schemes" that had been implemented massively after the financial crisis of 1997 (Kim, 2009).[4] These pioneer groups laid down the foundations of social enterprise in Japan and South Korea 
and gave a significant impetus to the development of related public policies.

Nonetheless, the most important single factor explaining the spreading of the social enterprise phenomenon in all these countries lies in the public policies that were implemented in the framework of the transitional welfare regimes and the globalisation process. Social enterprises in China are sprouting in the soil of the country's escalating market transition: the role of the socialist state as a social welfare provider has significantly shrunk, the market economy has grown dramatically and civil society organisations have achieved an expansive development (Yu, 2010). The financial crisis of 1997 brought about a similar socioeconomic context in Hong Kong, South Korea and Taiwan; it gave a direct impetus to reforms of welfare and employment policies aiming to better cope with new social problems. In Japan as well, the development of social enterprises is closely related with the welfare reform, especially the Social Welfare Law and the introduction of the Long Term Care Insurance system in 2000 (Laratta et al., 2010).

\section{Interactions with European and US experiences and schools of thought}

To explain the social enterprise phenomenon as it emerged in Eastern Asia, it is also important to identify the influence exercised by various Western experiences as well as by different schools of thought from both sides of the Atlantic. Beyond the general trends that go along with globalisation, we focus here on elements from the United States and Europe with which local actors in East Asia came into interaction and which contributed to the use of the notion of social enterprise itself or of very similar concepts.

\section{$\underline{\text { South Korea }}$}

In South Korea, an informal group of researchers and practitioners was set up in 1999 and played a role of pioneer in the country. In the same year, the concept of social enterprise was introduced through an article presented within a consulting group of researchers for the presidential cabinet (Kim, 1999). On the basis of European experiences, the concept became a subject of public debate on the occasion of an International Forum on social enterprise development, held in Seoul in 2000. As far as field initiatives are concerned, a "Social enterprise development agency" was established in 2001, in relation to the law on the National Basic Livelihood Security System (NBLSS) adopted in 1999. This agency played an active role in making the concept known both within local self-sufficiency centres (LSSCs)[5] and other traditional civil society organisations. 
Among the various countries surveyed here, South Korea is probably the one that has sent the highest number of visiting groups to Western Europe since the early 2000s. These groups were made of researchers, NGO leaders, civil servants from various departments and journalists. They were particularly interested in all kinds of new developments in the third sector and they found in European countries the two same components of the third sector as in their own country, namely co-operative enterprises and non-profit organisations. The notion of "social economy", in use in various parts of Europe as a synonym for the third sector, also began to be used in South Korea: in 2006 various federative bodies rooted in civil society movements (mostly non-profit organisations promoting social enterprise) established a large network under the name "Civil society's solidarity for the development of social enterprises" (CSSE),[6] and they held the first Social economy actors' Assembly in 2007.

More generally, as stated by Bidet (2008), the different legal forms and experiences of social enterprise launched in European countries and in the United States during the last 20 years served as references in South Korea to deal with the issue of unemployment and work integration and to shape the new law on social enterprise, passed in 2006. The official website of South Korean social enterprises - which, incidentally, is a governmental website - claims this dual influence from Europe and America. Among European models, it seems clear that the Italian "social co-operative" and the British "community interest company" were considered as major references. Like the Italian law of 1991, for instance, the Korean law refers to two main types of social enterprise, respectively for the provision of jobs and the provision of social services to disadvantaged groups. From several other European models, the Korean government took the notion of social enterprise as a label giving access to various types of support under clear conditions, while allowing "certified social enterprises" to incorporate under various legal forms.

\section{$\underline{\text { Japan }}$}

In Japan, the term "community business" has been more commonly used, to describe non-profit organisations or businesses with a hybrid character, than that of "social enterprise". Through the analysis of cases of successful community businesses in the United Kingdom, Hosouchi (1999, as quoted by Tsukamoto and Nishimura, 2009) had introduced that concept to describe similar activities in local community regeneration. However, Tsukamoto and Nishimura (2009) note that, in the early 2000s, emerging innovative organisations combining economic and social goals began to use, with increasing frequency, the concepts of social enterprise or social entrepreneur instead of 
that of community business, under the influence of US schools of thought,[7] the EMES European Research Network[8] and practitioners such as the Community Action Network and Social Enterprise London.

\section{$\underline{\text { China }}$}

According to Wang and Zhu (2009) and to Ding (2007), the concept of social enterprise was first introduced in China through the translation of an OECD draft report, published as a paper under the title "The Social Enterprise" in a volume of China Social Work Research (January 2004). Later in the same year, a "Sino-British Symposium on Social Enterprise and NPO" was jointly organised in Beijing by the Global Links Initiative and the China NPO Network, with financial assistance from the Cultural and Education Section of the British Embassy. Exchange visits of leading British social entrepreneurs and Chinese NGO leaders also took place. From 2006 onward, Chinese journals like China Economic Herald, Comparative Economic and Social Systems and the $21^{\text {st }}$ Century Business Review served as driving forces to spread the notion of social enterprise, together with the idea of social innovation.[9] In the same year, the translation of Bornstein's book How to Change the World and Leadbeater's The Rise of the Social Entrepreneur also had a significant influence, as did various Chinese organisations such as the China Social Entrepreneur Foundation and the NGO Research Centre at Tsinghua University. As noted in a report completed by the Non-Profit Incubator (2008) for the British Embassy, most publications since 2004 were introductions to British and American experiences and they did not make any distinction between social enterprise, social entrepreneur and social entrepreneurship. There was also some confusion, among business leaders and some experts, between social enterprise and CSR, because these two notions involve the same Chinese words.

Although still in an emerging phase, debates among researchers and practitioners focus on two questions: first, as to their identity, do social enterprises primarily belong to the NGO sector or to the world of corporations? Behind this question, a second one clearly appears: can social enterprises rely on various resources, such as donations and government subsidies, beside incomes from the service provision, or do they have to become self-sustainable by generating profits? Some authors consider that the fact of generating a large proportion of their income from the market is the most important point by which social enterprises differ from traditional NGOs. However, other authors consider that an organisation can also be considered as a social enterprise if it adopts innovative ways of fund-raising and explore all available resources, be it government subsidies, donations, or its own business revenue. 


\section{Hong Kong}

In Hong Kong, due to the financial crisis and the economic downturn, welfare expenditures increased significantly and public funding came under pressure in the late 1990s and the early 2000s. In such a context, the government launched employment assistance programs modelled on Western "social investment" and "welfare-to-work" approaches (Chan and Kuan, 2009). According to a report of a Commission on Poverty published in 2005 and quoted by Ho and Chan (2010), the welfare system was then transformed from "a passive system of benefit payment to the unemployed" to "an active system which encourages personal responsibility and facilitates employment". That Commission also recognised and advocated the use of social enterprises as a means to alleviate poverty and to improve skills level and employability. The various funding schemes initiated by the government and the publicity generated by the Poverty Commission really paved the way for the development of social enterprises in Hong Kong (Ho and Chan, 2010).

\section{$\underline{\text { Taiwan }}$}

According to Chan and Kuan (2009), social enterprises appeared in Taiwan in a context similar to the one in which they appeared in Hong Kong. However, these authors note that the government was also inspired by the European Union's Program "Third system, employment and local development", launched in the early 2000s. In such a perspective, the government began to provide a variety of resources to non-profit organisations to help them create job opportunities for specific target groups. As one can expect, other Western influences may be identified: in their review of the development of the nonprofit sector since the lift of the Martial Law in 1987, Kuan and Wang (2010) stress that NPOs with a commercial approach or for-profit business units emerged as early as the beginning of the 1990s; they refer explicitly to the Social Enterprise Alliance and various other authors from the United States.

\section{Forms, activities and features of social enterprises in East Asia: towards five broad models}

Although national contexts are quite different, with China of course on a very specific historical trajectory, it seems possible to identify at least five broad categories of initiatives which can be found in all the countries and territory analysed in this volume and may be referred to, albeit to varying degrees, as social enterprises. Such a typology 
has clear limits, as some social enterprises may belong to more than one category or may have only part of the distinctive features of a category. Moreover, it is clear that the notion of social enterprise is not used as such for most organisations classified here as social enterprises. However, we do argue that such a typology makes sense and can help to understand the convergences and divergences among East Asian countries and between the latter and other regions as regards the "social enterprise phenomenon".

\section{Model A: the "trading non-profit organisation"}

At first sight, this category may just look perfectly in line with the US dominant school of thought, which primarily sees social enterprises as non-profits developing earnedincome strategies to compensate for decreases in other sources of funding, such as public subsidies (Dees and Anderson, 2006; Kerlin, 2009). However, the East Asian context is quite different: this category does not necessarily stem from a large and wellestablished non-profit sector. It should rather be viewed as the result of a quite specific process, often constituted by two distinct steps. In a first stage, the state - which plays a prominent role in many aspects of economic and social life in Eastern Asia - made decisions to better recognise and promote dynamics and initiatives from an emerging civil society, in particular those addressing increasing social challenges. In a second stage or sometimes simultaneously, the state developed contractual relations with nonprofit organisations for the delivery of various services, in an effort to decentralise its action and/or to increase cost-efficiency.

In Japan, where large and well-endowed non-profits are quite regulated by the government, the major earthquake that happened in Kobe in 1995 generated a lot of spontaneous initiatives of solidarity and a massive increase in volunteering. This contributed to a higher awareness of the potential of civil society action and led the government to pass a new "NPO law". This law created a new, more flexible type of incorporated organisation for small and medium-sized non-profit and voluntary activities and enabled civic groups to acquire a legal status know as "NPO hojin" (Laratta et al., 2011, in this issue).

Since only few non-profits enjoy tax benefits and the Japanese society has a weak tradition of charitable giving, this new generation of non-profit enterprises relies mostly on the commercialisation of their services. Right after the Kobe earthquake, huge amounts of donations had been made to NPOs, but after 3 years or so, they declined drastically and NPOs had to engage in business-oriented activities to strengthen their financial viability (Fujii, 2008). Moreover, such a trend has been reinforced by the 
expansion of contractual relations with local authorities and the evolution of the public service sector toward "quasi-markets" since the late 1990s (Tsukamoto and Nishimura, 2009). The Long-Term Care Insurance system, implemented in 2000 in the field of services to the elderly, is emblematic of the influence of the New Public Management (NPM) paradigm. The hundreds of "takurojos" (elderly care institutions) operated under that system represent a major example of this type of social enterprise; they provide innovative and alternative forms of elderly-care services (Laratta et al., 2011, in this issue).

In South Korea, the third sector is still dominated by large foundations operating universities and hospitals under strong public regulation. Until recently, moreover, there was almost no room in the South Korean legal framework for small associations developing economic activities. Things began to change with the rapid growth of unemployment that followed the financial crisis of 1997. Under the new welfare regime, named "Productive welfare" and implemented in 1999, the state institutionalised the pilot project of "Self-help support programs"; social welfare corporations, named "community welfare centres" (CWCs), which had hitherto had a quasi monopoly in the provision of services to the disabled, the elderly or the poor, were forced to compete with other NPOs working for the unemployed or the socially disadvantaged to be certified as local self-sufficiency centres or to be commissioned to provide services within the framework of the Self-help support programs. Then, from 2003 onward, when the government launched the "Social employment creation scheme", which focused on the work integration of the working poor, new associations from the environmental, feminist and human rights movements joined massively the job creation movement, combining their own cause and that social purpose.

But resource competition is not the only motive explaining changes in the operational system of many social welfare corporations. Limits of charitable actions and scepticism about welfare services which had little positive results in terms of short-term poverty relief led social welfare corporations to adopt more innovative approaches.

In Taiwan, the non-profit sector has grown side by side with the country's process of democratisation since the late 1980s (Kuan and Wang, 2009). In the same period, the government introduced policies encouraging the privatisation of welfare services, with a view to lessening the fiscal burden, and it began to contract out service provision to commissioned NPOs. The latter took this opportunity to develop services paid by the users, moving towards a social enterprise model (Chan and Kuan, 2009).

In China, Ma (2002) underlines the rapid growth of NGOs (or non-profit organisations) in the late 1990s, a broad category in which she puts "social 
organisations" as well as "non-governmental non-commercial enterprises" - the latter's Chinese name also being translated as "civil (or civilian-run) non-enterprise institutions (or units)" (Lee, 2009; Yu and Zhang, 2009). In 1998 indeed, the state enacted regulations for both categories. According to Chinese official statistics, the number of civilian-run non-enterprise units reached 191,000 by the end of June 2010 (Ministry of Civil Affairs of China, 2010). These organisations are engaged in fields like education, health, science and technology, sports and various social services such as care for the elderly (a field where the number of care homes is particularly insufficient in Chinese cities). According to Wang and Zhu (2009), civilian-run non-enterprise units have three basic features: they can be established by enterprises, institutions, social organisations or other social powers or by individuals, but not by the government or governmental agencies; they are based on non-state-owned assets; and they cannot engage in profitmaking activities. However, although promoted by state policy under current reforms with a view to empowering civil society as a vehicle to solve major social problems, those organisations are facing major institutional challenges: the state imposes strict eligibility criteria and tries to retain control over them. Moreover, their legal status still lacks clarity: although non-profit in nature, most of them have to register as for-profit enterprises and therefore loose all tax exemption-related advantages.

As to Hong Kong, it presents a totally different historical pattern. Its non-profit sector has grown continuously from the late 1940s onward in field like educational, health, religious, cultural and recreational services, and it bears a high degree of similarities with its counterpart in the UK. Unlike the latter, however, as observed by Lam and Perry (2000), the non-profit sector in Hong Kong has long been considered as a residual one, due to the colonial heritage of a highly centralised power in the hands of the governor. It was only in the late 1990s that the New Public Management paradigm began to transform bureaucratic hierarchy into a nexus of contracts. Moreover, despite overall increases in welfare expenditures, due to the economic distress suffered by citizens after the financial crisis, government funding for NGOs declined during the 2000s (Ho and Chan, 2010). This of course exerted a considerable pressure on NGOs that had traditionally relied on government subsidies and it reinforced their incentive to look for other sources of funding, especially through market-oriented activities.

As a final remark about this first model of social enterprise, one should note that it embraces at least two distinct paths of NPO development towards commercialisation: such a process may take place within the NPO itself, which develops more business-oriented activities, or it may take the form of a new entity, for instance a for-profit company, set up by an existing NPO as a subsidiary (or sometimes 
as an independent entity) whose surpluses contribute to the NPO's financial viability. Let us also note that the light shed on commercialising NPOs may be combined, in the line of G. Dees (1998) and Ashoka's approach, with an emphasis on the heroic profile of the social entrepreneur, who brings about path-breaking social innovation. This is for example the approach adopted by authors like Tanimoto (2006) in Japan.

\section{Model B: the "work integration social enterprise" (WISE)}

Governments of all the surveyed countries and territory have developed policies to promote the creation of organisations taking care of vulnerable people excluded from the labour market. People with physical or mental disabilities are clearly a major target group in this regard, but other vulnerable groups may also be concerned. Such organisations offer more or less stable jobs to these persons or they offer them employment services, such as training and assistance to reintegrate the mainstream labour market.

Before looking at the various national experiences, it must be underlined that social enterprises of this category, which are defined by a very specific work integration mission, sometimes also belong to other categories: they may fulfil such a mission through an activity which increases their resources from market sales (model A); or they may stem from initiatives of the co-operative movements (model $\mathrm{C}$ ), from partnerships between private companies and non-profit organisations (model D), or from partnerships in a local development perspective (model E ).

According to Lee (2009) and to Wang and Zhu (2009), in China, "social welfare enterprises" - special businesses set up for the employment of people with physical or mental disabilities - are the prevalent form of social enterprises. In essence, they are tax-exempt for-profit firms with social goals. They represent a unique historical legacy from the socialist regime, but they have experienced strong pressures towards more economic efficiency due to the implementation of various new regulatory frameworks passed since the 1990s. As a result hereof, they may now be seen as China's first market-oriented operational model to help vulnerable people. However, they have been shrinking dramatically since the mid-1990s, although there were still around 23,000 social welfare enterprises across the country in 2008 , employing nearly 620,000 people with disabilities.

In Japan, since 1997, the employment of persons with disabilities has mainly been supported by a law imposing a quota system on private firms and public administration (1.8 per cent of their total workforce must be disabled workers). 
However, long before this law was passed - since the 1950s indeed -, a movement advocating for the creation of WISEs had spread in the country, and today there are many WISEs for persons with disabilities. As explained by Sakurai et al. (2009), some of these organisations offer transitional employment with a view to training their workers and helping them find a job in the mainstream labour market. Others provide permanent jobs, because the gap between their workers' actual skills and the productivity requirements in ordinary firms remains too large. Such workplaces are often called "common workshops", as they frequently mix workers with and without disabilities.

"Workers' collectives" are another important type of WISE in Japan. They are mainly set up by married women who cannot find full-time jobs because of their traditional housewife's responsibilities. These organisations often remain unincorporated, but their role in society is seen as more and more important as they provide social services such as long-term care and transportation services for the elderly and handicapped people and childcare services. Along with other authors, Inamura (2009) stresses the fact that such social enterprises are still weak in terms of both their financial and their human resource foundations. However, according to Sakurai et al. (2009), their number has increased rapidly since the mid-1990s, reaching 580 such collectives, with more than 16,000 workers, in 2003. More recently, co-operatives for the elderly also appeared, in which members try to find additional income through job opportunities as well as access to some social services.

According to Sakurai et al. (2009), new types of WISE have appeared since the mid 2000 s to bring about solutions to challenges such as the increasing number of homeless, socially withdrawn youth and immigrants. Under a program of the Ministry of Health, Labour and Welfare, 30 social enterprises have been commissioned to carry out projects to empower excluded young people through training camps. For the homeless, a special type of WISE started in 2003 as a Japanese version of the British Big Issue magazine: associations provide sales training and various self-support programs to the homeless who sell the magazine and can keep about half of the price for themselves.

In South Korea, "self-sufficiency enterprises"[10] were among the major expressions of the emerging civil society in the 1990s, so the government started pilot projects to support those worker co-operatives as a new instrument to address poverty problems. On a larger scale, the state launched public works programmes after the rise of unemployment in 1997 as well as work-integration ("self-help" or "self-sufficiency") schemes linked to the National Basic Livelihood Security System (NBLSS) introduced in 1999. Parts of these programmes were contracted out to specific NPOs, called "local 
self-sufficiency centres" (LSSCs). In 2007, 509 self-sufficiency enterprises, employing more than 3,000 workers, operated in various fields, such as construction, care services, cleaning, recycling, agriculture, manufacturing and so on (Bidet and Eum, 2010). Last but not least, the Law on the promotion of social enterprise, passed in 2006, stipulates work integration as one of the major roles of social enterprise. Among 251 certified social enterprises in 2009, more than 40 per cent (110) were of the work-integration type, using social employment creation schemes.

As to Hong Kong, Ho and Chan (2010) explain that the rapid development of WISEs in this region was strongly related to the drastic rise of unemployment (from 2.2 percent in 1997 to 7.9 percent in 2003) and to the adoption of a "welfare-to-work" approach in social welfare policies. More precisely, various programs were launched to "[enhance the] employment of people with disabilities through small enterprise" (2001) and to "[enhance] self-reliance through District partnership" (2006); this second program extended its target group to all vulnerable groups. Moreover, a "Community Investment and Inclusion Fund" was also launched in 2001 to support the reintegration of marginalised individuals into the labour market through social enterprises.

In Taiwan, as in Hong Kong, various types of social enterprises (non-profit social welfare agencies for the disabled, sheltered workshops,...) primarily emerged to provide disadvantaged people with training and employment services and opportunities. Taiwanese WISEs, however, differ from their counterparts in Hong Kong in that the former focus more on people with disabilities (Chan and Kuan, 2009). In 2002 especially, the Taiwanese government drew up "methods to establish and subsidise sheltered workshops for the physically and mentally disabled". Moreover, WISEs in Taiwan benefit from some policy measures which seem quite specific to that country. For instance, the Law for the protection of the mentally and physically disabled people and related policy measures call on all types of public institutions, public utility agencies and private schools receiving public grants to make at least 5 per cent of their total purchases from institutions for the disabled providing goods and services. Another form of public support is the assistance provided to social enterprises for the promotion of products through online sales platforms (Kuan and Wang, 2009).

Like the creation of LSSCs in South Korea, those last policy measures in Taiwan suggest that East Asian governments do not only strongly regulate the field of WISE; they also get actively involved in the promotion of these enterprises. In the US, such types of assistance would be provided by consulting companies or private foundations, while in Europe, they could come from networking bodies, such as the Italian "consorzi", community development agencies or third sector federations, 
although they could also be partly financed by public subsidies.

\section{Model C: the "non-profit co-operative" enterprise}

Some schools of thought, for example in the United States or Germany, tend to view cooperatives as for-profit enterprises just serving members' interests and having little in common with non-profit organisations, which pursue broader social purposes; in contrast to this view, important co-operative movements in most East Asian countries have played and are still playing a significant role in the shaping of the social enterprise landscape.

In Japan, various types of social enterprise are stemming or are being spun off from the co-operative movements. More specifically, the consumer co-operative movement (Seikyo movement), which developed rapidly from the 1970s onward, has given rise, during the last decades, to new types of co-operatives, with a social orientation. We already mentioned workers' collectives formed by women in urban areas to provide social services. There are also co-operatives for the elderly, healthcare cooperatives as well as co-operative initiatives to promote healthier food consumption, wind power production, fair trade and other societal goals.

As there is no specific legal status for workers' co-operatives in Japan, several authors refer to them as a "non-profit co-operative" (hieiri kyodo) model of social enterprise (Laratta et al., 2011, in this issue).

In South Korea, various initiatives stemming from new co-operative movements and aiming to promote and empower civil society could be included in this category of social enterprises, even though they do not represent a widely witnessed phenomenon at the national level. More particularly, most consumer co-operatives (including medical co-operatives and childcare facilities set up and run by parents) as well as workers' co-operatives are distinct from the traditional co-operative sector in various ways; they develop job creation activities for the disadvantaged, they create fair trade businesses with villages of poor producers of the Philippines and Eastern Timor, they develop care services, etc. The Association of alternative enterprises is trying to represent and give voice to these initiatives in a context where the government is keen on promoting the social enterprise sector.

Among the broad models of social enterprise identified in Hong Kong and Taiwan (generally oriented, as we have seen, towards the work integration of vulnerable groups), Chan and Kuan (2009) describe a "social co-operative model", which is established and owned by all members, who share an equal power in decision 
making. To underline the twofold - social and co-operative - nature of this model, these authors refer to the development patterns of social enterprise as defined by Decanay (2005): they place the social co-operative model under what she calls "an empowerment approach", focusing on the needs of the needy and stressing their sense of ownership.

In China, a huge co-operative sector (around 160 million families involved), mainly related to agricultural supply and marketing services, is under strict control by public authorities, and the organisations belonging to this sector can thus not be considered as social enterprises. However, it seems possible to argue that some new types of co-operatives are more social enterprise-like. More precisely, a recent law on "farmers' specialised co-operatives", enacted in 2006, is considered by Yu (2011, in this volume) as a public policy favouring social entrepreneurship. Governmental agencies do not have any significant supervision role on these co-operatives; members form the co-operative's governing body. The number of registered farmers' specialised cooperatives has reached 0.3 million, with roughly 25 million farmer members in 2010. From outside, it may not be obvious why these co-operatives would deserve a "social" qualification; in fact, the answer may lie in the fact that co-operatives in China are generally unions of disadvantaged people (Ding, 2007). On their side, Zhao and Develtere (2009) also stress some features of "shareholding co-operatives" as signs of a new indigenous model of social enterprise, because these organisations are more oriented towards the whole community or village than traditional co-operatives.

In various East Asian countries, traditional co-operatives were clearly - and are still, in some cases - submitted to strict regulations imposed by the state, which caused them to lose their voluntary nature and their focus on self-reliance and democratic governance. In the agricultural sector, in particular, co-operatives were often used as tools to provide cheap food and other kinds of resources to urban areas in the early stages of industrialisation. They also served as instruments of social control in times of colonisation and under military - or other non-democratic - regimes.

The emergence of a co-operative or non-profit co-operative model of social enterprise tends to suggest that state control, although it still exists, has become less pressing. In a more liberal and globalised economic context, however, the development of initiatives by vulnerable groups through such new types of co-operative probably also means that those people are less protected than before and have to find their way out by themselves. To a certain extent, such a situation may look similar to the $19^{\text {th }}$ century European context, from which the first co-operative initiatives emerged, as a response of poor workers and families to their own unmet needs. 


\section{Model D: the "social enterprise stemming from non-profit/for-profit partnerships"}

Partnerships between private companies and non-profit organisations are increasingly encouraged by governments. Moreover, private companies also take initiatives as part of their efforts to show their corporate social responsibility: in this perspective, they may set up social enterprise as subsidiaries or independent organisations to pursue a social mission.

In China, the Regulation on Foundation Administration, enacted in 2004, allowed private firms to set up private foundations; this constituted a new channel for them to take part in charitable activities. Private foundations also create new possibilities for closer partnerships between companies and non-profits. For companies with a CSR agenda, such partnerships constitute a means to improve their public image and reputation; and partnering with companies can help non-profits to receive more private contributions and to alleviate fiscal difficulties (Yu, 2011, in this issue). By the end of 2008, there were some 1,600 private foundations in China, and their number was increasing rapidly. Among them, the China Social Entrepreneur Foundation was the very first private foundation; it combines sponsorship by the state and funding from companies in China, Taiwan and Hong Kong to support sustainable poverty alleviation projects, mostly operated by non-profits.

In Taiwan and Hong Kong, Chan et al. (2011, in this issue) identify a model of social enterprise which they name the "joint venture model" or the "social venture model" and which refers to partnership activities jointly operated by NPOs and private companies.

In Japan, Tsukamoto and Nishimura (2009) identify a category of social enterprise stemming or spun off from business enterprises. For instance, NEC, a leading company in the field of information technology, has been engaged in fostering social entrepreneurs, in collaboration with a non-profit organisation.

In South Korea, partnerships for job creation started in 2001 between LSSCs and some conglomerates - Hanhwa and SK Telecom - within the framework of the Selfhelp support program. Strategic alliances with these companies helped LSSCs to partly solve the problem of lack of resources for equipments that they were facing, and that government subsidies did not allow solving. SK Telecom also established the "Sharing Happiness Foundation", in 2006, to support the creation of social enterprises delivering catering services and free school lunches.

Under the 2006 South Korean law on social enterprise, public authorities work not only with the non-profit sector but also with private for-profit companies. They especially try 
to contract out work integration and social services provision to private firms. They also aim to extend the resource mix of social enterprises by raising more funds from big corporations within the framework of the latter's policy of corporate social responsibility. Some major leading South Korean companies, such as Hyundai, have already started to offer a financial support to social enterprise initiatives (Bidet, 2008).

As a last remark about this model, we should say that it may be difficult to argue that a social mission is on equal footing with economic objectives when the firms involved are corporations developing social actions as instrumental practices to gaining market shares and increasing profits. However, one should also acknowledge that there exists a fast growing arena where practices such as venture philanthropy or some advanced CSR-related initiatives cannot be analysed with clear-cut boundaries.

\section{Model E: the "community development enterprise"}

Although the term "community" may refer to quite diverse groups or circles, it mostly refers to a whole population and local challenges in a specific area, and not just to one type of vulnerable people. Social enterprises in this category thus focus on community revitalisation or local development, often in rural disadvantaged areas. They try to rely on local resources (local culture and social bonds, local labour force and expertise,...) and they foster forms of community-based ownership, involving different types of stakeholders, be they non-profit, public or for-profit organisations or various groups including unemployed, homeless and other vulnerable persons. Overall, trying to create conditions enabling local people to stay where they live is a major driving force of this kind of initiatives.

In Japan, the "community business", has been a well-known concept since the early 1990s. It emerged with the goal of revitalising areas and towns facing structural difficulties (Fujii, 2008). Four main fields of activities developed by community businesses have been identified by researchers: renovation of local shopping streets, promotion of tourism in rural areas, encouraging environmental businesses, tackling social exclusion by creating new jobs for some groups (such as the elderly) within deprived communities. "Rural women entrepreneurship" can be seen as another major form of this social enterprise model in Japan. Indeed, thousands of "women-owned businesses" operate in rural areas; most of them are collectively managed. They develop farm-related activities such as food processing and distribution, restaurant as well as community and social services. This phenomenon attracted public attention in the early 1990s, but its origin goes back to the 1970s, when the food self-sufficiency movement 
was led by rural women (Kitajima, 2010).

The South Korean version of the community business is the "self-sufficient local community business", which has been spread since 2010 through a program of the Ministry of Public Administration and Security. It is not as such a specific type of social enterprise but rather a government-driven program, launched to promote initiatives responding to social problems in rural areas. However, a certain number of certified social enterprises are identified as belonging to this category by recent studies of this field, even though they are certified either as social enterprises of the job-providing type or of the service-providing type within the framework of the law on the Promotion of social enterprise ( $\mathrm{Ji}, 2010)$.

In Taiwan, Kuan and Wang (2010) stress the importance of "local community development enterprises", which are basically NPOs (or entities set up by the latter) which emerged from the community development movement.[11] From the early 1990s onward, this movement has been supported by various public programs with a view to reducing the gap between urban industrialised and rural areas. Such community-based NPOs seek to vitalise the local economy, improve living conditions, enhance residents' employability and raise people's willingness to take part in the local public arena.

As to China, it seems "farmers' specialised cooperatives" (FSC) may also be identified as a form of the community development enterprise. Since the promulgation of the Farmers' specialised cooperatives Law in 2006, FSCs have grown rapidly, as a new engine for rural economic development and community building in the design of the Chinese policy makers. By the end of June 2010, the number of officially registered FSCs has exceeded 0.3 millions and 25 millions farmer households (or 10 percent of China's total farm households) have become members of FSCs (Sun, 2010). Along similar lines, some authors like Zhao and Develtere (2009) argue that "shareholding cooperatives" are particularly oriented toward the local community as well: they put a strong emphasis on multiple-stakeholder ownership and they pursue goals which are economic, social and political (lessening tensions between farmers and local officials, offering a voice to farmers and workers, etc.).

Although it does not include all the examples of social enterprise reviewed above, table 3 synthesises our typology, based on the five emerging models we identified through the cross-country analysis.

\section{Table 3 - Typology of emerging social enterprise models in Eastern Asia}




\begin{tabular}{|c|c|c|}
\hline Broad models & Dynamics & $\begin{array}{l}\text { Corresponding forms or categories } \\
\text { in each East Asian country/territory }\end{array}$ \\
\hline $\begin{array}{c}\text { A. } \\
\text { Trading } \\
\text { NPO }\end{array}$ & $\begin{array}{l}\text { NPOs looking for other } \\
\text { sources of income or } \\
\text { seeking to achieve } \\
\text { financial sustainability } \\
\text { through the delivery of } \\
\text { social services (other than } \\
\text { work integration) }\end{array}$ & $\begin{array}{l}\text { - } \\
\text { - } \\
\text { Fee-for-service-providing NPO hojitiatives launched by social } \\
\text { welfare foundations (TW) } \\
\text { - } \\
\text { Subsidiaries of NPOs set up to earn market } \\
\text { income (HK) } \\
\text { - Fee-charging civilian-run non-enterprise units } \\
\text { (CN) } \\
\text { - } \text { Community welfare centres (SK) }\end{array}$ \\
\hline $\begin{array}{c}\text { B. } \\
\text { WISE }\end{array}$ & $\begin{array}{l}\text { Provision of (stable or } \\
\text { temporary) job } \\
\text { opportunities with } \\
\text { training and/or } \\
\text { employment services }\end{array}$ & 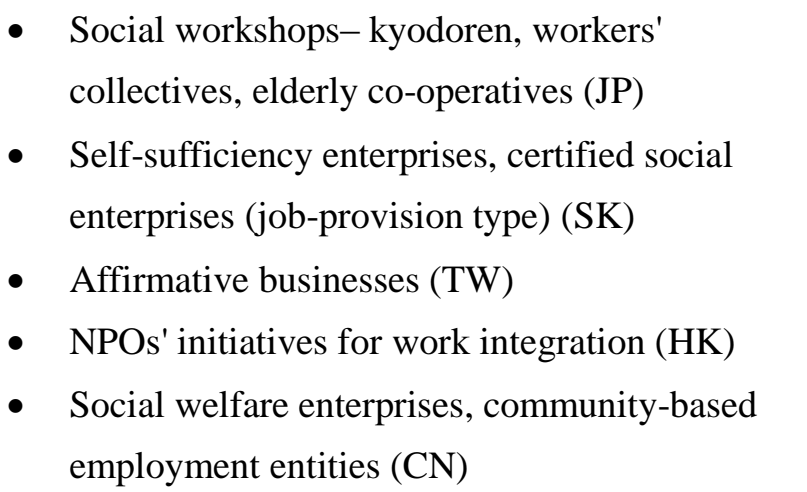 \\
\hline $\begin{array}{c}\text { C. } \\
\text { Non-profit } \\
\text { co-operative }\end{array}$ & $\begin{array}{c}\text { Collective self- } \\
\text { employment and } \\
\text { innovative responses to } \\
\text { unmet needs based on co- } \\
\text { operative tradition }\end{array}$ & $\begin{array}{l}\text { - Farmers' specialised co-operatives (CN) } \\
\text { - Workers' collectives, elderly co-operatives (JP) } \\
\text { - } \quad \text { Consumers' medical co-operatives, workers' co- } \\
\text { operatives (SK) } \\
\text { - Social co-operative-type initiatives operated by } \\
\text { NPOs (HK, TW) }\end{array}$ \\
\hline $\begin{array}{c}\text { D. } \\
\text { NPO-FPO } \\
\text { partnership }\end{array}$ & $\begin{array}{l}\text { Involvement of private } \\
\text { companies (or company } \\
\text { foundations) to support } \\
\text { NPOs or joint initiatives } \\
\text { with a social mission }\end{array}$ & - Social (joint) ventures (HK, TW, SK, JP, CN) \\
\hline $\begin{array}{c}\text { E. } \\
\text { Community } \\
\text { development } \\
\text { enterprise }\end{array}$ & $\begin{array}{c}\text { Multi-stakeholder } \\
\text { partnerships (NPO, FPO } \\
\text { and public) promoting } \\
\text { participatory local } \\
\text { development }\end{array}$ & $\begin{array}{l}\text { - Local community development organisations } \\
\text { (TW) } \\
\text { - Community businesses, rural women } \\
\text { entrepreneurship (JP) } \\
\text { - Self-sufficient local community businesses (SK) } \\
\text { - Farmers' specialised co-operatives (CN) }\end{array}$ \\
\hline
\end{tabular}




\section{Distinctive features of East Asian social enterprise models}

Are East Asian social enterprises different from their counterparts in Europe and North America, and if so, to what extent and why? There is of course no simple answer to such a question and the only relevant way to address this issue is probably to relate social enterprises, as they actually exist and operate, to their specific economic, social, political and cultural environment. More particularly, we think that studies on the "varieties of capitalism", the diversity of welfare regimes and the size and roles of civil society (third sector) organisations in such contexts would be particularly interesting bodies of literature to rely on. Such a task is clearly beyond the scope of this article, but we would like to simply stress here a few lines of thought which might be used for further research.

Although all social enterprises do not necessarily belong to the third sector, we do argue that this is actually the case of most social enterprises in Eastern Asia, as in Europe and North America, provided that the third sector itself is defined according to its overall environment in the various regions considered. On such a basis, we hold the view that the literature on the third sector, be it defined as the non-profit sector or the social economy, provides quite useful insights to understand the diversity of social enterprise landscapes across the world.

A pioneering attempt in such a perspective was made by Kerlin (2009), who chose to rely on the "social origins" theory, built by Salamon et al. (2000), to explain the diversity of social enterprise models across regions. Although her book only includes one chapter on Japan to cover Eastern Asia, she describes a typical Japanese model of social enterprise as a mix of interactions between the state, the market and, to a lesser extent, civil society, while the US model involves deep interactions between civil society and the market, with practically no influence from the state. As to the Western European model, she describes it as shaped primarily by interactions between civil society and the state, with a weaker role of the market than in the other two regions.

The country-specific typologies put forward in the other contributions to this volume as well as our cross-country typology presented here above can be considered as arguments against the very idea of a single typical model per country or region. However, at the world-wide level of comparison, it somehow makes sense to proceed with aggregate profiles - if not models - of social enterprise to shed light on key divergences. It is why we also present hereafter a figure based on those three classical spheres (i.e. the state, the market and civil society) already used, although differently, by Nicholls (2006) and Kerlin (2009). We particularly argue here that the East Asian social 
enterprise overall landscape is clearly marked by a strong and region-specific influence of state policy and that it is also moving towards an increasing role of civil society. We also stress the fact that an increasing part of the Western European landscape of social enterprises is relying on market or quasi-market mechanisms, although the very distinctive feature of social enterprise in that region is its central place in the graph, "at the crossroads of market, public policies and civil society" (Nyssens, 2006).

\section{Figure 1. Positioning of social enterprise for three regions}

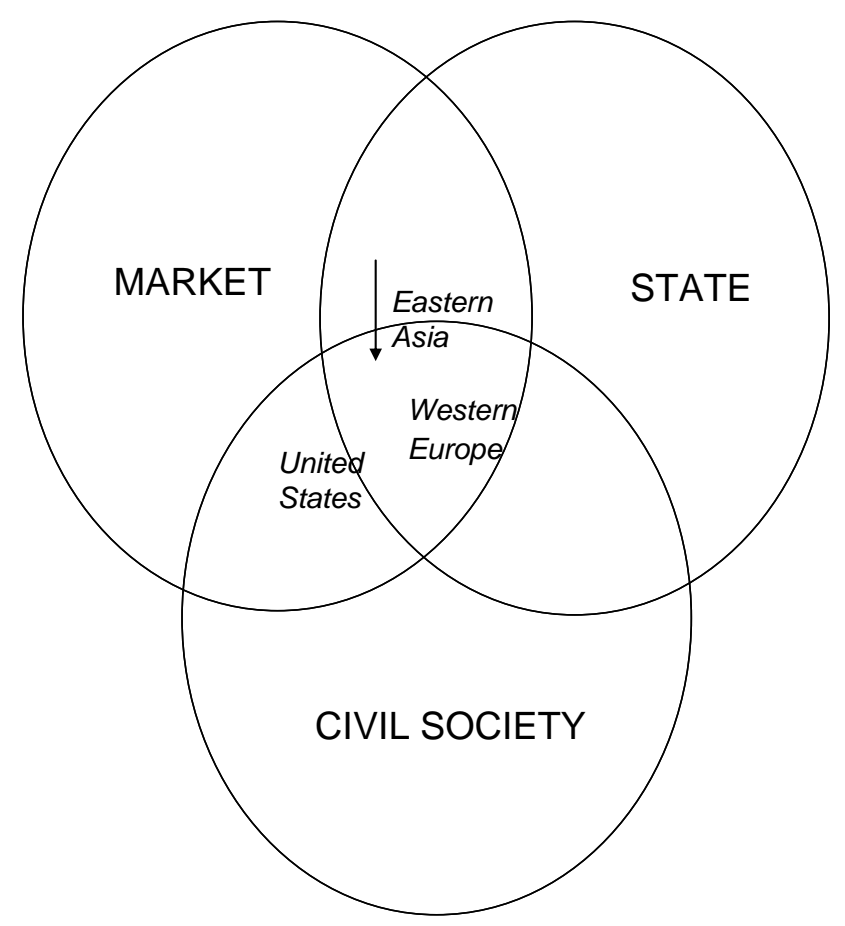

East Asian and Western European social enterprise landscapes do not only share a strong influence of public policies, although differently, as a common feature. They also both witness a significant involvement of co-operative movements - including the most recent ones in Eastern Asia, which less are dependent on the state than older generations of co-operatives. The role of such co-operative movements varies a lot across countries and types of social enterprise, with a stronger overall influence in China, Japan and South Korea than in Taiwan and Hong Kong. In any case, this leads us to propose a complementary insight, inspired by European history and current developments of the social economy, which typically embraces both co-operatives and non-profit organisations. 
When exploring the conditions of emergence and development of social economy organisations, Defourny and Develtere (1999) highlighted a "condition of necessity" and a "condition of shared destiny". Those authors stressed the fact that social economy organisations historically emerged during periods of major transformation of the prevailing economic system. Such deep transformations generally make it more difficult to meet some major needs and therefore create acute pressures referred to as the "condition of necessity".[12] However, the pressure exerted by necessity is not enough by itself to lead to the emergence of social economy initiatives: it can result in mere individual survival strategies, or in top-down public policy measures. Indeed, another driving force proved to be necessary in order for civil society and organised groups' initiatives to emerge in response to unmet pressing needs. On the basis of European and North American (Canadian) history, this driving force has been named the "condition of shared destiny": people sharing the same life conditions as an exploited working class or as poor peasants became aware of their collective potential and felt a powerful incentive to organise collectively innovative solutions to their problems.[13]

In contemporary Western European and North-American contexts, a quick and superficial assessment would suggest that the major basic needs which created a strong pressure of necessity in the $19 \mathrm{~h}$ century or the first half of the $20^{\text {th }}$ century have now been met by either the market or the welfare state, and that collective identities like those encountered in the old labour or agricultural movements more or less split up in the more advanced economies. However, a deeper analysis shows that although the nature of unmet pressing needs has changed, there are still plenty of them: the need for environmental protection, the need to fight against unemployment and social exclusion, the challenges related to fast aging populations, the need to integrate immigrants, the search for a fairer trade among rich and poor countries, the consumers' desire to buy better quality food products, etc. Around those contemporary challenges, people still get together to form co-operatives and non-profit organisations and try to find innovative solutions, often in partnership with foundations and private companies (like in the United States) or with public authorities at various levels (like in most Western European countries). Unlike the "pioneers" of the social economy, these people do not necessarily share a strong collective identity, but their awareness of specific challenges nevertheless brings them together with a same feeling of "shared destiny"; and the more people learn about key challenges, the more they are potentially able to take action together. However, the splitting up of strong collective identities as well as the increased average level of education and living conditions probably make it easier for individuals 
to become social entrepreneurs without necessarily relying on a collective dynamics from the very outset.[14]

As we have just seen, the key conditions of necessity and shared destiny have to be reinterpreted according to current contexts; this is true when speaking of a same region at different periods but also, obviously, when speaking of different regions. In Eastern Asia, most of the contemporary challenges mentioned above may also be found. More particularly, a major pressure resulted from the deep financial crises which hit most countries in the late 1990s as well as from the rapid rise of unemployment which followed. The lack of well-structured social protection for some vulnerable groups also became more acute. Moreover, natural disasters like the Great Hanshin-Awaji Earthquake of 1995 or the major overflows that occurred in South Korea and China also generated a particularly strong "pressure of necessity". In a completely different context, such a pressure was also felt much earlier by Japanese rural women who had to contribute to their own family budget damaged by an acreage-reduction policy in the 1970s which also forced their husband to leave agriculture and to look for a job in town. They not only took responsibility of the hard work of farming for their in-house consumption, they also became entrepreneurs to develop products for the market.

As for the condition of shared destiny, many authors would argue that the civil society is weaker and only emerging in East Asian countries which were for long governed by an authoritarian state. As a result hereof, the chances to find autonomous civil society attempts to invent new solutions to current social problems might seem weaker. But once again, a deeper analysis may suggest a more nuanced perspective. First, we should certainly acknowledge the role of public authorities in shaping the third sector/social economy and therefore the social enterprise phenomenon - a role which represented a stronger force in Eastern Asia than in Western countries. Secondly, some social and cultural foundations of East Asian societies, related to a tradition of Confucianism, tend to favour values such as loyalty to the ruling entity as well as the search for wisdom and social harmony, instead of direct confrontation. Can such vertical relations between individuals and the state fuel a sense of shared destiny within society? The answer would probably be positive with respect to the sense of belonging to a common nation and various forms of patriotism. But then, is this likely to provide an impulse to citizens' joint initiatives to address societal problems? Some would argue that this is unlikely and that, on the contrary, people in such a context will expect the state to take the lead. They might add that such a state does not reflect a "social contract" among citizens, and that since a social contract is often said to be the very deep foundation of Western-style civil society and democracy, state-citizens relations in East Asian 
countries seem unfavourable to the emergence of civil society initiatives.

However, in front of major events such as natural disasters (a threat shared by the whole population), one witnessed the emergence or the strengthening of voluntary charitable and mutual aid initiatives. The size of such moves in terms of philanthropic giving and volunteering was really striking during the relief operations following the earthquake of 1995 in Kobe and the flood of 1998 in China.[15]. Other examples, among many others, are provided by local communities who resisted when the globalisation of the economy and structural adjustment programs imposed by international institutions threatened their own way of life and traditions. For instance, aboriginal communities in Taiwan launched alternative local development initiatives as did many local communities in Japan. For such groups, the community is more than an administrative or geographical demarcation. It is a space for a self-help network where they seek to assure livelihoods. Surpluses are not said to be "reinvested" but "returned' to the community for it is the latter which provides resources and know-how [16]. More generally, many authors have noted the particular importance of horizontal informal networks based on kinship, neighbourhood or other social relations.

All this suggests that an East Asian-style "social cement" can be identified behind the apparent prevalence of vertical state domination. In other words, we definitely argue that, provided one does not analyse East Asian realities through "Western lenses", one can observe an indigenous version of community or "shared destiny" driving force at work in the emergence and development of social economy at large as well as in recent social enterprise developments. Even more so, natural disasters as they occurred might be seen as an outstanding expression of both conditions at the same time: as creating a pressing necessity and leading to strong answers from people facing a shared destiny.

Let finally note that this may be truer for some categories of social enterprises, such as those to which we referred as models B, C and E in table 3 and which may be seen as involving a stronger community-based component.

\section{Conclusions}

Our comparative study of the social enterprise phenomenon in East Asian countries shows a rather complex landscape, which invites researchers to be cautious and to remain quite open to diverse approaches of social enterprise. In those countries indeed, social enterprises have been developing relatively late in comparison to the Western Europe and the United States; therefore, influences from those latter regions combined in East Asia with endogenous factors to inspire a diversity of actors in various ways, 
thus resulting in a wide variety in the social enterprise landscape.

Nevertheless, it seems clear that a somehow common denominator to all East Asian countries is the fact that the state power, which is strong in these countries, has been playing a key role in the emergence and development of social enterprises, not only in terms of regulation but also as a driving force in shaping models, through related policy measures and associated funds. At the same time, market forces have also played a critical role, as many public policy measures tend to push social enterprises closer to the regular market and various initiatives are also launched in partnership with traditional private companies.

In this context, a key question for the future of East Asian social enterprise is whether, under such forces of isomorphism (Di Maggio and Powell, 1983), exerted simultaneously by the state and the market, social enterprises will be able to maintain their distinct features. Indeed, there are always risks for social enterprises to be slowly transformed social into some kinds of "subsidiaries" of public agencies (Kuan and Wang, 2009; Ma, 2002). On the other side, the competition for securing market income, with a view to achieving financial independence, can also lead social enterprises to give an increasing importance to economic goals and possibly to lose sight of their social mission or to weaken it.

In European works on the social and solidarity economy, it is often underlined that the hybridisation of various types of resources may constitute a quite valuable safeguard to resist isomorphic pressures: by mixing market incomes, public (direct and indirect) subsidies and non-monetary resources, such as volunteering and in-kind donations, social enterprises can better avoid the domination of a single logics of action. Empirical evidence on European WISEs strongly confirms such a hypothesis (Nyssens, 2006). As to Eastern Asia, we learn from the country studies in this volume that the trend toward market reliance is mitigated by various types of public support in several social enterprise models.

Finally, the issue of autonomy raises the question of the governance of social enterprise. Are there governance models which may prove more appropriate for social enterprises to ensure both their autonomy and their focus on social goals? While the EMES "ideal-type" social enterprise underlines a participatory dynamics in the governance structure, US schools of thought seem to pay less attention to this matter. In Eastern Asia, the question is clearly raised by the Law promoting social enterprise in South Korea [17] as well as by models inspired by the cooperative tradition (model C) or relying on multi-stakeholder ownership (model D). On this topic however as for many other issues, more efforts toward in-depth field research are certainly needed in 
order to move forward in the comparative analysis of social enterprises across regions.

\section{Footnotes}

1. A major part of the literature on the non-profit sector since the mid-1970s has dealt with the conditions under which NPOs have emerged and developed in modern economies.

2. As this article has been written along with country papers during the whole joint research project, we also refer to earlier versions of these papers, presented at the "International Conference on Social Enterprises in Eastern Asia: Dynamics and Variations", in Taipei (June 14-16, 2010) or at EMES International Conferences held in Barcelona (2008) and in Trento (2009).

3. East Asian countries are situated more or less in a sensitive zone in geopolitical terms, due to the region's colonisation history. South Korea and Taiwan have rather sensitive relations respectively with North Korea and China, while Hong Kong has independent judiciary functions and enjoys a high degree of autonomy but under mainland China's sovereignty. Japan is not affected directly by tensions among neighbouring countries, but those tensions are often perceived as representing a danger to national security.

4. OSCUs were a kind of federations of associations established at the local and regional levels in order to respond to urgent social problems linked to unemployment through multiple actions (urgent relief, counselling, job coaching and job creation, etc.).

5. A specific structure approved by the Ministry of health and welfare and run by various NPOs stemming from the urban poor movement, the unemployed (workers') movement and religious groups.

6. CSSE decided to restructure its network in 2008 by grouping all the components of the social economy which considered themselves as belonging to civil society and it changed its name to become the "Solidarity for the social economy".

7. Following Dees and Anderson (2006), there are two major US schools of thought: the "social innovation school of thought", led by Dees (1998), and the dominating "earned income school of thought", as it has been renamed by Defourny and Nyssens (2010).

8. The first EMES book (Borzaga and Defourny, 2001), on "The Emergence of Social Enterprise" in Europe, was translated and published in Japanese in 2005.

9. It is also interesting to note that, the Compilation and Translation Bureau of the 
Communist Party Central Committee was involved in the follow-up of various international conferences and various publications.

10. Most of these initiatives, also named "self-help communities", took the form of workers' co-operatives.

11. In their comparative analysis of Hong Kong and Taiwan, Chan et al. (2011, in this issue) underline that this model of social enterprise is specific to Taiwan.

12. In Europe, especially during the $19^{\text {th }}$ century and the beginning of the $20^{\text {th }}$ century, the bulk of the population felt terribly pressing needs with respect to access to affordable food products, healthcare, credit, better prices for agricultural production, better paid jobs and so on.

13. Credit co-operatives, worker co-operatives, consumer and agricultural cooperatives were born from such a combination of the condition of necessity and the condition of shared destiny. In some countries or areas, such a shared destiny was made particularly strong by a kind of "integrated collective identity": for instance, rural areas deeply rooted in Catholicism and speaking poorly recognised languages (such as French in Canada, Flemish in Belgium and Basque in Spain) were dominated by urban elites speaking the ruling language (English in Canada, French in Belgium, and Castillan in Spain) and sometimes belonging to other religious groups (like Protestants in industrialised Canadian cities).

14. This point should not be over-emphasised: charismatic and/or better educated leaders can be found as well at the very foundation of many "historical" social economy organisations.

15. Ma (2002) stresses that, in contrast to the widely noted symptoms of social corrosion, impressive numbers of Chinese people have been dedicating themselves to "doing good".

16. In this sense, community development social enterprises in East Asian countries show a certain kinship with the "European Neighbourhood Enterprises" inspired by the French "régies de quartier" and with "solidarity or popular economy organisations" in Latin America (De França Filho, 2005),

17. The law on the promotion of social enterprise in South Korea requires the participation of different stakeholders in the decision-making structures as a condition to be certified as a social enterprise, but there are no exact criteria allowing to assess to what extent this requirement is met or not.

\section{References}


Bidet, E. (2008), "The Rise of Work Integration and Social Enterprise in South Korea", paper presented at the 2d EMES-ISTR International Conference, July 9-12, University of Barcelona.

Bidet, E. and Eum, H. (2010), "Social Enterprise in South Korea: History and Diversity", Paper presented at the International Conference on "Social Enterprises in Eastern Asia: Dynamics and Variations", Taipei, June 14-16.

Borzaga, C. and Defourny, J. (Eds) (2001), The Emergence of Social Enterprise, Routledge, New York (paperback edition: 2004). Japanese translation: Hyoronsha, 2004. Korean translation: Sigma Press, 2009.

Borzaga, C., Galera, G. and Nogales, R. (Eds) (2008), Social Enterprise: A New Model for Poverty Reduction and Employment Generation. UNDP Regional Bureau, Bratislava.

Chan, K. (2008), "Creative Philanthropy: Development of Social Enterprise in Hong Kong", paper presented at the $2^{\text {nd }}$ EMES-ISTR International Conference, July 912, University of Barcelona.

Chan, K. and Kuan, Y. (2009), "A Tale of Two Regions: A Comparative Study of Social Enterprises in Hong Kong and Taiwan", paper presented at the $2^{\text {nd }}$ EMES International Conference on Social Enterprise, University of Trento.

Dacanay, M.L. (2005), "Getting A Handle on Social Entrepreneurship", Paper presented at Open Symposium on Social Entrepreneurship, Taiwan, February 18, 2005.

Dees, J. G. (1998), "The Meaning of Social Entrepreneurship", Working Paper, Kauffman Center for Entrepreneurial Leadership.

Dees, J. G. and Anderson, B. B. (2006), "Framing a Theory of Social Entrepreneurship: Building on Two Schools of Practice and Thought", in Research on Social Enterpreneurship ARNOVA Occasional Paper Series, Vol.1, No. 3, pp.39-66.

Defourny, J. (2001), "From third sector to social enterprise", in Borzaga, C. and Defourny, J. (Eds), The Emergence of Social Enterprise, Routledge, London and New York, pp. 1-28.

Defourny, J. and Develtere, P. (2009), "Origines et contours de l'économie sociale au Nord et au Sud", in Defourny, J., Develtere, P. and Fonteneau, B. (Eds), L'économie sociale au Nord et au Sud, De Boeck, Brussels and Paris, pp. 25-56. English version available at: http://www.emes.net/fileadmin/emes/PDF_files/Articles/Defourny/Defourny.De veltere_SE_NorthSouth_Chap1_EN.pdf

Defourny, J. and Nyssens, M. (2008), "Social Enterprise in Europe: Recent Trends and 
Developments", Social Enterprise Journal, Vol.4, No. 3, pp. 202-28.

Defourny, J. and Nyssens, M. (2010), "Conceptions of Social Enterprise and Social Entrepreneurship in Europe and the United States: Convergences and Divergences", Journal of Social Entrepreneurship, Vol.1, No. 1, pp. 32-53.

De França Filho, G. (2005), "Une dynamique associative emblématique au Nord-Est brésilien", in Laville, J.-L., Magnen, J.P., de França Filho, G.C., and de Medeiros, A., (Eds.), Action publique et économie solidaire, Editions Erès, Paris.

Di Maggio, P. J. and Powell, W.W. (1983), "The iron cage revisited: institutional isomorphism and collective rationality in organizational fields", American Sociological Review, No. 48, pp. 147-60.

Ding, K. (2007), "Social Enterprise: Practice in China", in Demos (Ed.), Social Enterprise Overview: A UK and China Perspective, British Council, Beijing.

Fujii, A. (2008), Civil Society and Development of Social Enterprise in Japan, Rikkyo University, mimeo.

Ho, A.P. and Chan, K.-T. (2010), "The Social Impact of Work-Integration Social Enterprises in Hong Kong", International Social Work, Vol. 53, No. 1, pp. 33-45. available at: http://isw.sagepub.com/cgi/content/abstract/53/1/33 (accessed May $10,2010)$.

Imamura, H. (2009), "Relational Skills for Solving Multi-stakeholder Problems in the Provision of Personal Social Services through Social Enterprises and Local Governments in Japan", paper presented at the $2^{\text {nd }}$ EMES International Conference on Social Enterprise, University of Trento.

Ji, K. (2010), "Implementing integrated support system for social enterprises and community businesses", Policy Brief, Seoul (in Korean).

Jones, C. (1993), "The Pacific Challenges: Confucian Welfare State", in Jones, C. (Ed.), New Perspectives on the Welfare State in Europe, Routledge, London and New York.

Kanno, M. (2000), "20 Years' Performance and Future Perspective", paper presented at the International Forum on Social Enterprise Development (in Korean).

Kerlin, J. (2009), "A Comparison of Social Enterprise and its Contexts", in Kerlin, J. (Eds.), Social Enterprise, A Global Comparison, Tufts University Press, Lebanon, NH.

Kim, S. (1999), "The Social Enterprises in Europe and their Contribution to Employment Policy", paper presented to the Planning team for the quality of life.

Kim, S. (2009), "The Dynamics of Social Enterprise in South Korea", EMES Conferences Selected Papers Series, ECSP-T09-10. 
Kitajima, K. (2010), "Practice and Theory of Social Entrepreneurship in Japan", draft paper presented at the International Conference on "Social Enterprises in Eastern Asia: Dynamics and Variations", Taipei, June 14-16.

Kuan, Y. and Wang, S. (2009), "Is Government's Intervention Too Much? An Analysis of the Impact of Public Authorities on the Development of Social Enterprises in Taiwan", EMES Conferences Selected Papers Series, ECSP-T09-02.

Kuan, Y. and Wang, S. (2010), "Taiwanese Social Enterprises: Characteristics, Development Trends and Effects", Paper presented at the International Conference on "Social Enterprises in Eastern Asia: Dynamics and Variations", Taipei, June 14-16.

Kwon, H.-J. (Ed.) (2005), Transforming the Developmental Welfare State in East Asia, Palgrave/UNRISD, Houndmills.

Lam, W. and Perry, J. (2000), "The Role of the Nonprofit Sector in the Hong Kong's Development", Voluntas, Vol. 11, No. 4, pp. 355-73.

Lee, R. (2009), "The Emergence of Social Enterprises in China: the Quest for Space and Legitimacy", paper presented at the $2^{\text {nd }}$ EMES International Conference on Social Enterprise, University of Trento, July 1-4..

Ma, Q. (2002), "The Governance of NGOs in China since 1978: How much Autonomy?", Nonprofit and Voluntary Sector Quarterly, Vol. 31, No.3, pp. 30528.

Ministry of Civil Affairs of China (2010) Statistical report on national civil affairs of the second quarter of 2010 ,

available at: http://files2.mca.gov.cn/cws/201007/20100727184754202.htm (accessed 15 November 2010)

Nicholls, A. (Ed.) (2006), Social Entrepreneurship, New Models of Sustainable Social Change, Oxford University Press, New York.

No, D., Kang S., Lee H., Yang S. and Lee E. (2008), Study on Korean Welfare Model, KIHASA, Seoul.

Nyssens, M. (Ed.) (2006), Social Enterprise - At the Crossroads of Market, Public Policies and Civil Society, Routledge, New York.

Salamon, L. S., Sokolowski, W. and Anheier, H. K. (2000), "Social Origins of Civil Society: An Overview", Working Paper of the Johns Hopkins Comparative Nonprofit Sector Project, No. 38, the Johns Hopkins Center for Civil Society Studies, Baltimore.

Sakurai, M., Nakagawa, S. and Laratta, R. (2009), "Exploring the Distinctive Feature of Social Enterprise in Japan", draft paper prepared for the Joint Research Project 
of East Asian researchers and the EMES European Research Network.

Sun, Zhonghua, 2010, "Speech at the conference on farmers' specialised cooperatives and the institutional innovation of rural economy", available at: http://www.cfc.agri.gov.cn, (accessed on August 15, 2010) (in Chinese).

Tanimoto, K. (Ed.) (2006), Sosharu Entapuraizu (Social Enterprise), Chuokeizaisha, Tokyo.

The Non-Profit Incubator (2008), The general report of social enterprise in China, Report commissioned by the British Council, Beijing.

Tsukamoto, I and Nishimura, M. (2009), "Japan", in Kerlin, J.A. (Ed.), Social Enterprise: A Global Comparison, University Press of New England, Hanover and London, pp. 163-83.

Wang, M and Zhu, X. (2009), "A General Overview on Theory and Practice of Chinese Social Enterprise", paper presented at the $2^{\text {nd }}$ EMES International Conference on Social Enterprise, University of Trento, July 1-4.

Wilding, P. (2008), "Is the East Asian Welfare model still productive?", Journal of Asian Public Policy, Vol.1, No. 1, pp. 18-31.

Yu, X. (2010), "Social Enterprise in China: Context, Features and Challenges", paper prepared for the Joint Research Project of East Asian Researchers and the EMES European Research Network on the Emergence of Social Enterprise in Eastern Asia.

Yu, X. and Zhang, Q. (2009), "Development of Social Enterprise under China's Market Transition", paper presented at the $2^{\text {nd }}$ EMES International Conference on Social Enterprise, University of Trento, July 1-4.

Zhao, L. and Develtere, P. (2009), "New Co-operatives in China: Why They Break Away from Orthodox Co-operatives", Social Enterprise Journal, Vol. 6, No. 1, pp. 35-48.

Young??? 